\title{
Lung apoptosis after intra-pulmonary instillation of Benzo(a)pyrene in Wistar rats $^{1}$
}

\author{
Apoptose pulmonar após instilação intrapulmonar de Benzo(a)pireno em ratos Wistar
}

\author{
Baldomero Antonio Kato da Silva ${ }^{\mathrm{I}}$, Ricardo Dutra Aydos" ${ }^{\text {II }}$ Iandara Schettert Silva ${ }^{\mathrm{II}}$, Daniel Martins Pereira ${ }^{\mathrm{III}}$, Paulo de Tarso \\ Camillo de Carvalho ${ }^{\mathrm{IV}}$, Doroty Mesquita Douradov , Filipe Abdalla dos Reis ${ }^{\mathrm{I}}$, Renato Silva Nacer ${ }^{\mathrm{II}}$ \\ ${ }^{I}$ Fellow PhD Degree, Health and Development of the Central West Region, UFMS and Associate Professor, Anhanguera-Uniderp, Brazil. \\ ${ }^{\text {II }} \mathrm{PhD}$, Associate Professor, UFMS, Campo Grande-MS, Brazil. \\ III Master, Health and Development Post Graduation from UFMS and Associate Professor at Anhanguera-Uniderp, Campo Grande-MS, Brazil. \\ Iv $\mathrm{PhD}$, Orthopedics, Traumatology and Rehabilitation, Sao Paulo University (USP) and Associate Professor, UFSE, Brazil. \\ ${ }^{v} \mathrm{PhD}$, Cellular Biology and Structural Histology, UNICAMP and Associate Professor, Anhanguera-Uniderp, Brazil.
}

\begin{abstract}
Purpose: To evaluate the influence of pulmonary instillation of Benzo[a]pyrene in lung apoptosis of Wistar rats. Methods: Male Rattus norvegicus albinus, Wistar lineage was carried through an intra-pulmonary instillation of the Benzo[a]pyrene (B[a]P) dilution in alcohol 70\%. Three experimental groups had been formed with 08 animals each: Control Group (Alcohol 70\%); B[a]P Group 40 mg/kg; e B[a]P Group $80 \mathrm{mg} / \mathrm{kg}$, submitted to euthanasia 16 and 18 weeks after the experimental procedure. The pulmonary sections had been processed by TUNEL method and submitted to the histomorphometric analysis to quantify the apoptotic cell number. Results: After 16 weeks, mean of apoptotic cells number in control group $(19,3 \pm 3,2)$ was greater than $40 \mathrm{mg} / \mathrm{Kg}$ group $(11,8 \pm 1,9 ; \mathrm{p}<0,01)$ and $80 \mathrm{mg} / \mathrm{Kg}$ group $(7,0 \pm 1,4 ; \mathrm{p}<0,01)$. Significant difference also observed between $40 \mathrm{mg} / \mathrm{Kg}$ and $80 \mathrm{mg} / \mathrm{Kg}(\mathrm{p}<0,05)$. After 18 weeks, mean of apoptotic cells number in control group $(18,0 \pm 2,2)$ was greater than $40 \mathrm{mg} / \mathrm{Kg}$ group $(8,8 \pm 1,7 ; \mathrm{p}<0,01)$ and $80 \mathrm{mg} / \mathrm{Kg}$ group $(5,5 \pm 1,3 ; \mathrm{p}<0,01)$. Significant difference wasn't observed between $40 \mathrm{mg} / \mathrm{Kg}$ and $80 \mathrm{mg} / \mathrm{Kg}$ (ns). Conclusion: Intra-pulmonary instillation of Benzo[a]pyrene induces significant decrease of apoptotic activity in lung tissue.
\end{abstract}

Key words: Apoptosis. Benzo(a)pyrene. Lung Neoplasms. Carcinogens. Rats.

\section{RESUMO}

Objetivo: Avaliar a influência da instilação intrapulmonar de Benzo[a]pireno na apoptose pulmonar de ratos Wistar. Métodos: Rattus norvegicus albinus, linhagem Wistar machos foram submetidos à instilação intra-pulmonar da diluição em álcool 70\% de Benzo[a]pireno (B[a]P). Foram formados três grupos experimentais com 08 animais cada: Grupo Controle (álcool 70\%); Grupo B[a]P 40 mg/kg; e Grupo B[a]P $80 \mathrm{mg} / \mathrm{kg}$, submetidos a eutanásia 16 e 18 semanas após o procedimento experimental. As secções pulmonares foram processadas pelo método TUNEL e submetidas à análise histomorfométrica para quantificação do número de células apoptóticas. Resultados: Após 16 semanas, a média do número de células apoptóticas do grupo controle $(19,3 \pm 3,2)$ mostrou-se maior que o grupo $40 \mathrm{mg} / \mathrm{Kg}(11,8 \pm 1,9 ; \mathrm{p}<0,01)$ e $80 \mathrm{mh} / \mathrm{Kg}(7,0 \pm 1,4 ; \mathrm{p}<0,01)$. Diferença significante foi também observada entre os grupos 40mg/Kg e $80 \mathrm{mg} / \mathrm{Kg}(\mathrm{p}<0,05)$. Após 18 semanas, a média do número de células apoptóticas do grupo controle $(18,0 \pm 2,2)$ mostrou-se maior que o grupo $40 \mathrm{mg} / \mathrm{Kg}(8,8 \pm 1,7 ; \mathrm{p}<0,01)$ e $80 \mathrm{mh} / \mathrm{Kg}(5,5 \pm 1,3 ; \mathrm{p}<0,01)$. Não foi observada diferença significante entre os grupos 40 e $80 \mathrm{mg} / \mathrm{Kg}$ (ns). Conclusão: A instilação intrapulmonar de Benzo[a]pireno induziu diminuição significativa da atividade apoptótica em tecido pulmonar.

Descritores: Apoptose. Benzo(a)pireno. Neoplasias Pulmonares. Carcinógenos. Ratos.

${ }^{1}$ Research performed at Postgraduate Program in Heath and Development of the Central West Region, Federal University of Mato Grosso do Sul (UFMS), Campo Grande, Brazil. 


\section{Introduction}

Lung cancer is one of most prevalent cancers in the world, and its mortality is expected to remain very high for many years to come. Because lung cancer does not show any symptoms in early stage of the disease, the majority of patients with this cancer are diagnosed with metastasis. Searching for prognostic indicators of lung cancer is an important clinical issue ${ }^{1-3}$.

Cancer arises principally as a consequence of exposure of individuals to carcinogenic agents in what they inhale or eat and drink, or through exposures at their work or elsewhere. Rather than inherited genetic characteristics, other factors play the major roles in the etiology of cancer. These include personal habits such as tobacco use, dietary patterns, and occupational exposure to carcinogens ${ }^{4}$.

Environmental air pollution and smoking habits are the main sources of inhalation exposure to carcinogenic agents such as polycyclic aromatic hydrocarbons (PAH), products of incomplete combustion of organic matter and are widespread in the environment. PAHs, such benzo[a]pyrene $(\mathrm{B}[\mathrm{a}] \mathrm{P})$, are currently recognized as one of major classes of environmental carcinogenic pollutants ${ }^{5}$.

Carcinogenic and mutagenic effects of $\mathrm{B}[\mathrm{a}] \mathrm{P}$ have been well documented in humans, animals, and mammalian cell systems. In general, $\mathrm{B}[\mathrm{a}] \mathrm{P}$ is among the more potent known experimental carcinogens. Active metabolites bind covalently to DNA and thus result in DNA damage ${ }^{1}$.

Apoptosis or programmed cell death is a highly organized process to eliminate damaged or abnormal cells, and occurs under several physiological and pathological situations, and it represents a common mechanism of cell replacement and tissue remodeling. It is involved in maintaining homeostasis in multicellular $\operatorname{organisms}^{6,7}$.

Apoptosis is characterized by nuclear and cytoplasmatic condensation of single cells (shrinkage) followed by loss of the nuclear membrane fragments of the nuclear material and cytoplasm - apoptotic bodies. Biochemical features associated with apoptosis include internucleosomal cleavage of DNA, leading to an a oligonucleosomal "ladder", phosphatidylserine externalization and proteolytic cleavage of a number of intracellular substrates ${ }^{8}$.

Because of disregulation of apoptosis in cancer, studies that define the potential apoptotic markers to serve as prognostic or predictive factors in cancer are of critical importance. Defects in the processes controlling apoptosis can extend cell life span through neoplastic cell expansion independently of cell division. In addition, they contribute to carcinogenesis by creating a permissive environment for genetic instability and accumulation of gene mutations, promoting resistance to immune-based destruction, and allowing disobedience of cell cycle checkpoints that would normally induce apoptosis ${ }^{9}$.

The aim of this study was to evaluate the influence of pulmonary instillation of benzo[a]pyrene in lung apoptosis of Wistar rats.

\section{Methods}

Male Rattus norvegicus albinus, Wistar lineage 08 to 12 weeks of age were obtained from UFMS animal colony. Animals were housed four per cage on hard-wood chip bedding and were given food and purified tap water. Rats were randomized into treatment groups and were quarantined for 2 ad libitum weeks prior to treatment, during which time they were acclimatized to 12-h light-dark cicles.

$\mathrm{B}$ [a]P was suspended in alcohol $70 \%$ to obtain 40 and 80 $\mathrm{mg} / \mathrm{ml}$ concentrations. Rats were anesthetized with a mixture of ketamine and xilazine, positioned in supine and a thoracocentesis with a 13 X4,5 needle was realized in left lung.

Rats (eight per group) were given a single intrapulmonary instillation of B[a]P at doses of 40 and $80 \mathrm{mg} / \mathrm{kg}$ using a 1-ml sterile syringe that was attached to the needle. The animals (four by four) were killed 16 and 18 weeks after the intrapulmonary instillation. A group of 08 rats (control) were also instilled with alcohol $70 \%$.

Until their sacrifice, all animals were maintained four per cage under controlled ambient conditions and with free access to food and water. Rats were killed by intraperithoneal infusion of lethal dose of sodium penthobarbital.

The pulmonary sections were processed for enzyme terminal deoxy-nucleotidyl transferase (TdT)-mediated dUTP nick end labeling (TUNEL) and submitted to the histomorphometric analysis performed with the aid of the Image Pro Plus program (version 4.5.0.29).

Statistical evaluation was performed using Analysis of Variance followed Tukey's post hoc test. Student's t test was used for pairwise comparison. The difference was considered significant when $p<0,05$. The statistical procedures were followed with the aid of Bioestat 5.0 statistical software. All experiments respected the international rules for animal experimentation.

\section{Results}

Apoptotic cells number were identified in all slices of control and experimental groups. The apoptotic cells were identified as irregular nuclear membrane staining. There was statistically significant difference among all the groups when analyzed the time and dose-response data ( $\mathrm{p}<0,001$; ANOVA) (Table 1).

TABLE 1 - Mean $( \pm \mathrm{sd})$ of apoptotic cells number in the various animal's groups

\begin{tabular}{l|c|c}
\hline & $\mathbf{1 6}$ weeks & $\mathbf{1 8}$ weeks \\
\hline Control Group & $19,3 \pm 3,2$ & $18,0 \pm 2,2$ \\
\hline B[a]P 40 mg/Kg Group & $11,8 \pm 1,9$ & $8,8 \pm 1,7$ \\
\hline B[a]P 80 mg/Kg Group & $7,0 \pm 1,4$ & $5,5 \pm 1,3$ \\
\hline
\end{tabular}

Figures 1 and 2 shows the mean values (and standard deviation) of apoptotic cell number values for the 16 and 18 weeks of the control, $40 \mathrm{mg} / \mathrm{Kg}$ and $80 \mathrm{mg} / \mathrm{Kg}$ groups.

Figure 3 shows the mean values (and standard deviation) of groups when realized pairwise comparisons. 


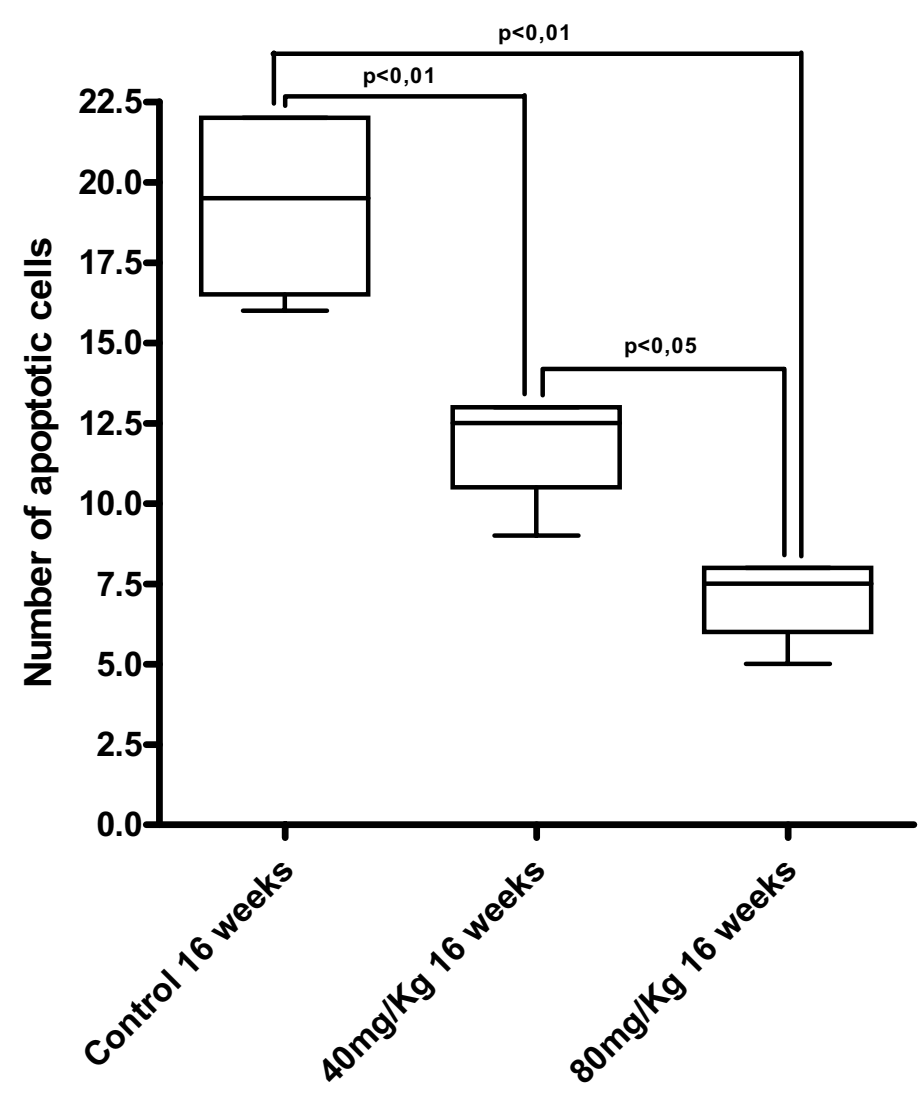

FIGURE 1 - Mean and standard deviation of number of apoptotic cells in all groups after 16 weeks

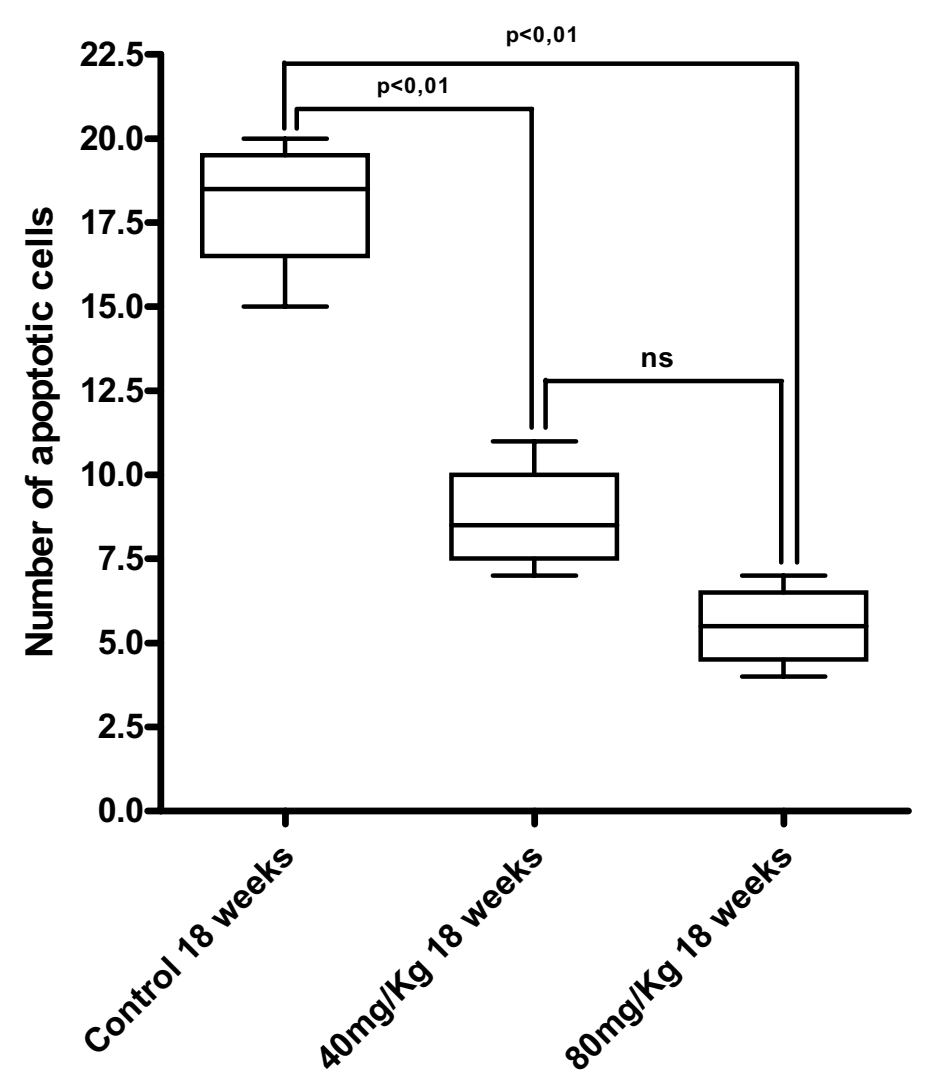

FIGURE 2 - Mean and standard deviation of number of apoptotic cells in all groups after 18 weeks

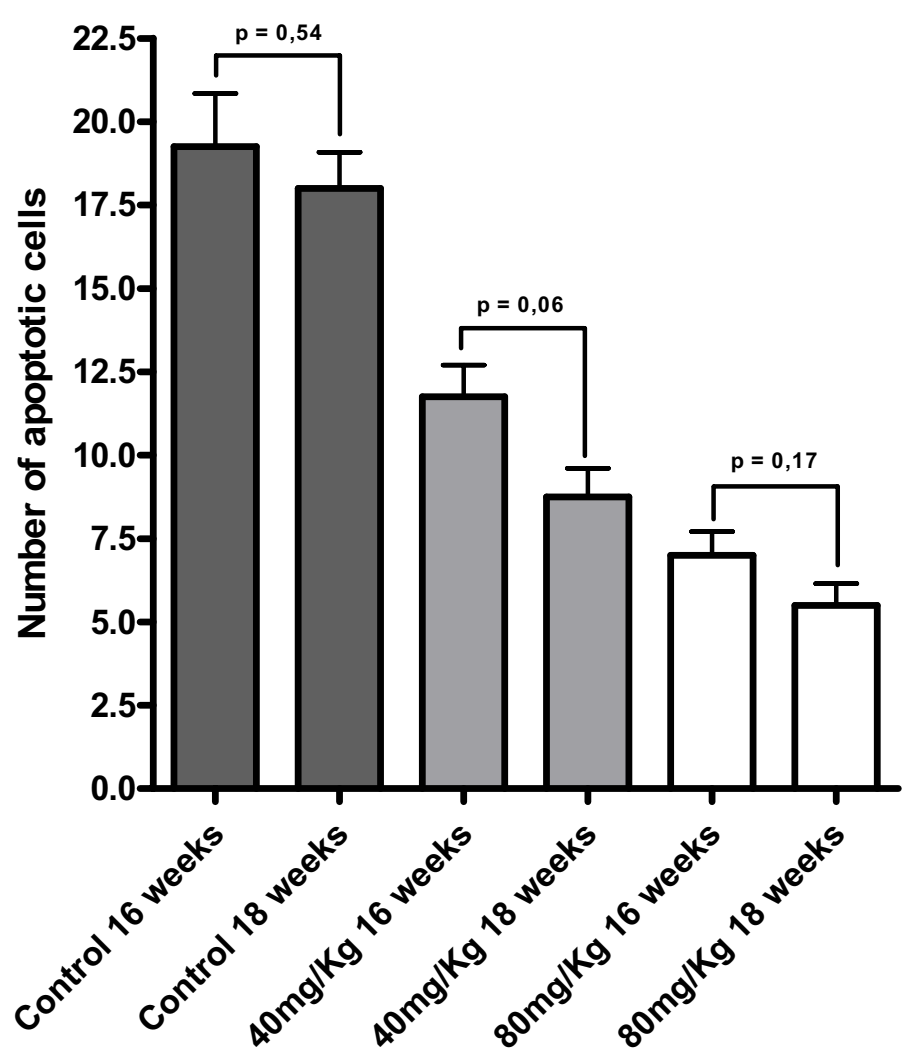

FIGURE 3 - Pairwise comparison between the control and experimental groups

\section{Discussion}

Apoptosis has been implicated in a wide range of pathological conditions. Decreased apoptosis is involved in cancer and autoimmune disorders. Neoplastic disease was typically envisaged as result from defects in these pathways leading to excess cell division, and alterations of apoptotic mechanisms play important roles in carcinogenesis and tumor growth ${ }^{8}$.

In this study, apoptotic cells were identified as irregular nuclear membrane staining in $400 \mathrm{X}$ magnification. Light microscopic assessment is a standard method for apoptosis investigation. However, because of small size and typically scattered distribution of apoptotic cells and apoptotic bodies in lung tumors, high magnification objectives are needed for studying apoptosis on routine light microscopy ${ }^{10}$.

Although morphological characteristics described apoptosis, it is now clear that there is a highly complex molecular process involved. Genes implicated in animal and human carcinogenesis are a significant regulators of the process of apoptosis ${ }^{6}$.

All the groups presented inflammatory process in lung tissue. Garçon et al. ${ }^{12}$ suggest that the exposition to an associated oxidant agent to the carcinogenic ones induces greater release of pro-inflammatory mediators, contributing to the process of carcinogenesis activation. Apoptosis of structural cells is frequently observed in inflammatory lung diseases ${ }^{11,12}$.

Focal inflammatory areas were frequently observed in previous studies involved experimental models of lung cancer. In this study, apoptotic cells presence in all groups may be explained by inflammatory process secondary to cancer induction method ${ }^{5}$. 
Repair after an acute lung injury requires the elimination of inflammatory cells from the alveolar airspace or alveolar wall. Clearance of apoptotic cells has an important role in the resolution of inflammatory lung injury ${ }^{13}$.

The analysis of the available literature, references had not been found on the accurate reply-dose of $\mathrm{B}[\mathrm{a}] \mathrm{P}$ enough to the induction of pulmonary carcinogenesis, however it observes that at the studies which outcomes related the instillation of $\mathrm{B}[\mathrm{a}] \mathrm{P}$ to tissular alterations, molecular or genetic in the lungs, the doses had varied between $10 \mathrm{mg} / \mathrm{kg}$ and $50 \mathrm{mg} / \mathrm{kg}^{12,14}$.

Benzo[a]pyrene is often used as a model compound for polycyclic aromatic hydrocarbon family, and has been shown to be a potent lung carcinogen ${ }^{15}$.

The clonal cell expansion depends of proliferating lack of control and increased incapacity of apoptosis death. Therefore, despite greatly cancer variability, apoptosis resistance is a most important characteristic of malignant tumors ${ }^{16}$.

The finds of this study showed that apoptosis suppression was connected with time and dose of carcinogenic utilized. Analysis of tumor genesis revealed that death resistance capacity can be acquired by different mechanisms, how contact with external soluble factors, especially carcinogenic agents ${ }^{16}$.

Similar results were observed by Kwon et al. ${ }^{17}$ after intra-tracheal injection of cadmium into both rats lungs. Authors observed a time-response decrease of apoptotic cells ${ }^{17}$.

\section{Conclusion}

Intra-pulmonary instillation of Benzo(a)pyrene induces significant decrease of apoptotic activity in lung tissue. Understand apoptotic mechanism and apoptosis-signaling molecules may lead novels strategies in lung cancer therapy.

\section{References}

1. Pei XP, Nakanishi Y, Takayama K, Bai F, Hara N. Benzo[a]pyrene activates the human $\mathrm{p} 53$ gene through induction of nuclear factor kappaB activity. J Biol Chem. 1999;274(49):35240-6.

2. Sangrajrang S, Sornprom A, Chernrungroj G, Soussi T. Serum p53 antibodies in patients with lung cancer: correlation with clinicopathologic features and smoking. Lung Cancer. 2003; 39:297-301.
3. Lopez-Gonzales JS, Prado-Garcia H, Aguilar-Cazares D, MolinaGuarneros JA, Morales-Fuentes J, Mandoki JJ. Apoptosis and cell cycle disturbances induced by coumarin and 7-hydroxicoumarin on human lung carcinoma cell lines. Lung Cancer. 2004;43:275-83.

4. World Health Organization. Policies and managerial guideliness for national câncer control programs. Rev Panam Salud Publica. 2002;12(5):366-70.

5. Silva BAK, Silva IS, Pereira DM, Aydos RD, Carvalho PTC, Facco GG. Experimental model of pulmonary carcinogenesis in Wistar rats. Acta Cir Bras. 2007;22 Suppl 1:16-20.

6. Taraphdar AK, Roy M, Bhattacharya RK. Natural products as inducers of apoptosis: implication for cancer therapy and prevention. Curr Sci. 2001;80(11):1387-96.

7. Carnevali S, Petruzzelli S, Longoni B, Vanacore R, Barale R, Cipollini M, Scatena F, Paggiaro P, Celi A, Giuntini C. Cigarette smoke extract induces oxidative stress and apoptosis in human lung fibroblasts. Am J Physiol Lung Cell Mol Physiol. 2003;284:955-63.

8. Brajuskovic GR. Apoptosis in malignant diseases. Arch Oncol. 2005;13(1):19-22.

9. Walaszek Z, Hanausek M. Molecular markers of apoptosis as prognostic indicator in cancer. Cell Biol Mol Lett. 2000;5(2): 278-9.

10. Gaffney EF, O’Neill AJ, Staunton MJ. In situ end-labelling, light microscopic assessment and ultrastructure of apoptosis in lung carcinoma. J Clin Pathol. 1995;48:1017-21.

11. Banjerdpongchai R. Oxidative stress related apoptosis in smokers and chronic lung diseases. Chiang Mai Med Bull. 2006;45(4):173-84.

12. Garçon G, Gosset P, Garry S, Marez T, Hannothiaux MH, Shirali P. Pulmonary induction of proinflammatory mediators following the rat exposure to benzo(a)pyrene-coated onto Fe2O2 particles. Toxicol Lett. 2001;121:107-17.

13. Kwano K, Yoshimi M, Maeyama T, Hamada N, Yamada M, Nakanishi Y. Apoptosis signaling pathways in lung diseases. J Med Chem. 2005;1(1):49-56.

14. Rubin H. Synergistic mechanisms in carcinogenesis by polycyclic aromatic hydrocarbons and by tobacco smoke: a bio-historical perspective with updates. Carcinogenesis. 2001;22(12):1903-30.

15. Harrigan JA, Vezina CM, McGarrigle BP, Ersing N, Box HC, Maccubbin AE, Olson JR. DNA adduct formation in precision-cut rat liver and lung slices exposed to benzo[a]pyrene. Toxicol Sci. 2003;77:307-14. 16. Grivicich I, Regner A, Rocha AB. Morte celular por apoptose. Rev Bras Cancerol. 2007;53(3):335-43.

17. Kwon KY, Jang JH, Kwon SY, Cho CH, Oh HK, Kim SP. Cadmium induced acute lung injury and TUNEL expression of apoptosis in respiratory cells. J Korean Med Sci. 2003;18:655-62.

\section{Correspondence:}

Baldomero Antonio Kato da Silva

Rua Beirute, 289

79112-150 Campo Grande - MS Brazil ftbaldock@uol.com.br

Conflict of interest: none

Financial source: none

\section{How to cite this article}

Silva BAK, Aydos RD, Silva IS, Pereira DM, Carvalho PTC, Dourado DM, Reis FA, Nacer RS. Lung apoptosis after intra-pulmonary instillation of Benzo[a]pyrene in Wistar rats. Acta Cir Bras. [serial on the Internet] 2010 Jan-Feb;25(1). Available from URL: http:// $\underline{\text { www.scielo.br/acb }}$ 